\title{
The Value of Energy Performance and Green Attributes in Buildings: A Review of Existing Literature and Recommendations for Future Research
}

Labels, certifications, and rating systems for energy efficiency performance and "green" attributes of buildings have been available in the U.S. for over 10 years, and used extensively in the European Union and Australia for longer. Such certifications and ratings can make energy efficiency more visible, and could help spur demand for energy efficiency if these designations are shown to have a positive impact on sales or rental prices. This policy brief discusses the findings and methodologies from recent studies on this topic, and suggests recommendations for future research. Although there have been just a handful of studies within the last 10 years that have investigated these effects, a few key findings emerge:

- To maximize sales price impact, label or rating information must be disclosed early and visibly in the sales process;

- The approach to evaluating energy efficiency labels (e.g., ENERGY STAR) and general "green" certifications (e.g., LEED or GreenPoint Rated) may need to be different, depending on the type, vintage and market penetration of the label;

- Collaborative efforts to promote label adoption and build a large dataset of labeled buildings will be required to produce reliable study results.

\section{Home Performance Labels Overview}

Table 1 provides a non-exhaustive summary of building labels, certifications, and rating systems currently in use in North America and Europe, grouped and listed in the following order: U.S. nationwide, U.S. regional and statewide, and international. In the U.S. residential sector, there are currently four primary nationally-available building performance certifications or rating systems: 1) the ENERGY STAR Qualified New Homes label ${ }^{1}$ for new homes; 2) the LEED ${ }^{2}$ tiered certification system for new homes and

\footnotetext{
${ }^{1}$ ENERGY STAR Qualified New Homes Version 3 is being rolled out in 2011-2012 and requires homes to be at least 15-20\% more energy efficient than homes built to the 2009 International Energy Conservation Code (IECC).

This paper is part of the LBNL Clean Energy Program Policy Brief series. These working papers highlight emerging program models, important issues that new programs face, and how these issues are being addressed. To join the email list to receive these policy briefs, please click HERE. The work described in this Policy Brief was funded by the Department of Energy Office of Energy Efficiency and Renewable Energy, Weatherization and Intergovernmental Program under Contract No. DE-AC02-05CH11231. Please direct questions or comments to Elizabeth Stuart (estuart@lbl.gov).
}

DISCLAIMER

This document was prepared as an account of work sponsored by the United States Government. While this document is believed to contain correct information, neither the United States Government nor any agency thereof, nor the Regents of the University of California, nor any of their employees, makes any warranty, express or implied, or assumes any legal responsibility for the accuracy, completeness, or usefulness of any information, apparatus, product, or process disclosed, or represents that its use would not infringe privately owned rights. Reference herein to any specific commercial product, process, or service by its trade name, trademark, manufacturer, or otherwise, does not necessarily constitute or imply its endorsement, recommendation, or favoring by the United States Government or any agency thereof, or the Regents of the University of California. The views and opinions of authors expressed herein do not necessarily state or reflect those of the United States Government or any agency thereof or the Regents of the University of California. 
existing homes that have undergone renovation; 3) the National Association of Home Builders' National Green Building Standard; and 4) the Home Energy Rating System (HERS) Index ${ }^{3}$, used by new home builders as well as home performance programs and contractors to provide energy performance ratings for existing homes. The HERS rating provides a comparison to a typical home in the region and can be used as part of an energy upgrade for baseline assessment and to measure estimated savings of the upgrade.

The U.S. Department of Energy (DOE) is conducting pilots to develop a new nationwide label, the Home Energy Score, which indicates the current level of energy efficiency of a home and includes recommendations for energy improvements. DOE plans to develop a national home energy registry in conjunction with roll-out of this program, potentially enabling homebuyers to look up the energy efficiency rating of a home that they are considering for purchase. ENERGY STAR and LEED certification are also available in the commercial sector, for new construction, major renovations, and energy or "green” upgrade projects.

Building energy labels have also been developed for new and/or existing homes at the regional level. These labeling programs certify that homes meet a threshold for a broad array of "green” attributes (akin to LEED), including Build it Green's GreenPoint Rated certification in California, the EarthCraft House $^{\mathrm{TM}}$ and EarthCraft Renovation programs in the Southeast, and the Earth Advantage New Homes certification program in the Pacific Northwest. The Earth Advantage label incorporates its Energy Performance Score, which provides an estimate of actual home energy consumption and ranks that energy use against other homes regionally and nationally.

Most European countries have completed development of mandatory time-of-transfer energy performance certification requirements, as part of efforts to comply with the European Union (EU) Energy Performance of Buildings Directive (EPBD). The EPBD was approved in 2003 and set a December 2008 implementation deadline for all member nations. Australia also mandates energy use disclosure for all homes on the market.

\footnotetext{
${ }^{2}$ Leadership in Energy and Environmental Design (LEED) is a program of the U.S. Green Building Council and rates buildings' level of energy and resource efficiency and occupant and community health impacts.

${ }^{3}$ The HERS Index is a scoring system established by the Residential Energy Services Network (RESNET) whereby a home built to the specifications of the HERS Reference Home (based on the 2006 International Energy

Conservation Code) scores a HERS Index of 100, while a net zero energy home scores a HERS Index of 0.
} 


\section{Table 1. Summary of selected building labels or rating systems}

\begin{tabular}{|c|c|c|c|c|c|c|}
\hline Label & $\begin{array}{c}\text { Sponsor (Geographic } \\
\text { Scope) }\end{array}$ & Market & Label Type & Rating Method & Application & URL \\
\hline \multicolumn{7}{|l|}{ U.S. NATIONAL } \\
\hline $\begin{array}{l}\text { ENERGY STAR Qualified } \\
\text { New Homes }{ }^{\text {a }}\end{array}$ & EPA (U.S.) & Residential - new & $\begin{array}{l}\text { Binary certification based on detailed } \\
\text { mandatory checklists and performance }\end{array}$ & $\begin{array}{l}\text { Checklists and variable HERS } \\
\text { Index threshold }\end{array}$ & Voluntary - homebuilders & $\begin{array}{c}\text { http://www.energystar.gov/index.cfm } \\
\text { ?c=new_homes.hm_index }\end{array}$ \\
\hline $\begin{array}{l}\text { ENERGY STAR } \\
\text { Commercial }\end{array}$ & EPA/DOE (U.S.) & $\begin{array}{l}\text { Commercial - new construction or } \\
\text { major renovations }\end{array}$ & $\begin{array}{l}\text { Binary certification - energy } \\
\text { performance based on operational } \\
\text { score }\end{array}$ & $\begin{array}{l}\text { EPA energy performance } \\
\text { rating system }\end{array}$ & $\begin{array}{l}\text { Voluntary - developers, owners, } \\
\text { managers and tenants }\end{array}$ & $\begin{array}{l}\text { http://www.energystar.gov/index.cfm } \\
\text { ?c=new_bldg_design.new_bldg_design }\end{array}$ \\
\hline Home Energy Score & DOE (U.S.) & Residential - existing & Energy performance scale & $\begin{array}{l}\text { Proprietary assessment tool; } \\
\text { keeps some assumptions } \\
\text { constant }\end{array}$ & $\begin{array}{l}\text { Voluntary - compare energy use } \\
\text { between properties }\end{array}$ & $\begin{array}{c}\text { http://www1.eere.energy.gov/buildin } \\
\text { gs/homeenergyscore/ }\end{array}$ \\
\hline E-Scale/HERS Index & DOE (U.S.) & Residential - existing & Energy performance scale & HERS Index & $\begin{array}{l}\text { Voluntary - homebuilders and } \\
\text { homeowners }\end{array}$ & $\begin{array}{l}\text { http://www1.eere.energy.gov/buildin } \\
\text { gs/challenge/energysmart.html }\end{array}$ \\
\hline LEED ${ }^{\oplus}$ for Homes & $\begin{array}{l}\text { US Green Building Council } \\
\text { (U.S.) }\end{array}$ & $\begin{array}{l}\text { Single-family and multifamily } \\
\text { residential - new construction and } \\
\text { renovations }\end{array}$ & $\begin{array}{l}\text { 3-tiered point-based certification - } \\
8 \text { categories }{ }^{\mathrm{b}}\end{array}$ & $\begin{array}{l}\text { Proprietary rating system, } \\
\text { includes HERS rating - third } \\
\text { party verified }\end{array}$ & $\begin{array}{l}\text { Voluntary - homebuilders and } \\
\text { homeowners }\end{array}$ & $\begin{array}{c}\text { http://www.usgbc.org/DisplayPage.asp } \\
\text { x?CMSPagelD=147 }\end{array}$ \\
\hline $\begin{array}{l}\text { LEED我 commercial rating } \\
\text { systems }\end{array}$ & $\begin{array}{l}\text { US Green Building Council } \\
\text { (U.S.) }\end{array}$ & $\begin{array}{l}\text { 1) New Construction } \\
\text { 2) Operations \& Maint. } \\
\text { 3) Commercial Interiors } \\
\text { 4) Core \& Shell } \\
\text { 5) Schools } \\
\text { 6) Retail } \\
\text { 7) Healthcare }\end{array}$ & $\begin{array}{c}\text { 4-tiered point-based certification } \\
\text { (Certified, Silver, Gold, Platinum) - } \\
7 \text { categories }^{c}\end{array}$ & LEED documentation process & $\begin{array}{l}\text { Voluntary - developers, owners, } \\
\text { managers and tenants }\end{array}$ & $\begin{array}{c}\text { http://www.usgbc.org/DisplayPage.asp } \\
\text { x?CategorylD=19 }\end{array}$ \\
\hline $\begin{array}{l}\text { National Green Building } \\
\text { Standard }{ }^{\mathrm{Tm}}\end{array}$ & $\begin{array}{c}\text { National Association of } \\
\text { Homebuilders (NAHB) } \\
\text { (U.S.) }\end{array}$ & $\begin{array}{l}\text { Single and multifamily residential - } \\
\text { new contruction and renovations }\end{array}$ & $\begin{array}{c}\text { 4-tiered point-based certification } \\
\text { (Bronze, Silver, Gold, Emerald) - } \\
6 \text { categories }^{{ }^{d}}\end{array}$ & $\begin{array}{l}\text { NAHB online Green Scoring } \\
\text { Tool; rough and final } \\
\text { inspections by third party } \\
\text { verifier accredited by NAHB } \\
\text { Research Center }\end{array}$ & $\begin{array}{l}\text { Volundary - developers, builders } \\
\text { and owners }\end{array}$ & $\begin{array}{c}\text { http://www.nahbgreen.org/NGBS/defa } \\
\text { ult.aspx }\end{array}$ \\
\hline \multicolumn{7}{|l|}{ U.S. REGIONAL/STATE } \\
\hline $\begin{array}{l}\text { Energy Performance } \\
\text { Score }\end{array}$ & $\begin{array}{l}\text { Earth Advantage Institute } \\
\text { (U.S. Pacific Northwest) }\end{array}$ & Residential - new and existing & Energy performance scale & $\begin{array}{l}\text { HERS and proprietary } \\
\text { calculator }\end{array}$ & $\begin{array}{l}\text { Voluntary - for comparing usage } \\
\text { between properties }\end{array}$ & $\begin{array}{c}\text { http://www.earthadvantage.org/progr } \\
\text { ams/homes/energy-performance- } \\
\text { score/ }\end{array}$ \\
\hline
\end{tabular}

a ENERGY STAR Qualified Homes Version 1 (1995) 30\% more efficient than a home built to the 1992 Model Energy Code (MEC). Version 2 (2006) 15\% more efficient than IECC 2004. Version 3 (2011-2012): 15-20\% more efficient than IECC 2009.

${ }^{b}$ Innovative design process; locations \& linkages; sustainable sites; water efficiency; energy \& atmosphere; materials \& resources; indoor environment quality; awareness \& education.

c Innovation in design, sustainable sites, water efficiency, energy and atmosphere, materials \& resources, indoor environment quality, regional priority.

d Lot development; construction resource efficiency; energy efficiency; water efficiency; Indoor environmental quality; operation, maintenance and building owner education. 
Table 1. Summary of selected building labels or rating systems (continued)

\begin{tabular}{|c|c|c|c|c|c|c|}
\hline Label & $\begin{array}{c}\text { Sponsor (Geographic } \\
\text { Scope) }\end{array}$ & Market & Label Type & Rating Method & Application & URL \\
\hline \multicolumn{7}{|l|}{ U.S. REGIONAL/STATE } \\
\hline $\begin{array}{l}\text { Earth Advantage } \\
\text { Certified New Homes }\end{array}$ & $\begin{array}{l}\text { Earth Advantage Institute } \\
\text { (U.S. Pacific Northwest) }\end{array}$ & Residential - new & $\begin{array}{l}\text { Binary certification for performance in } \\
\qquad 5 \text { categories } \mathrm{e}\end{array}$ & $\begin{array}{l}\text { Earth Advantage assessors; } \\
\text { two visits - during rough-in } \\
\text { and on completion }\end{array}$ & Voluntary-homebuilders & $\begin{array}{c}\text { http://www.earthadvantage.org/progr } \\
\text { ams/homes/earth-advantage-new- } \\
\text { homes/ }\end{array}$ \\
\hline EarthCraft House ${ }^{m}$ & $\begin{array}{c}\text { Southface (Southeastern } \\
\text { U.S.) }\end{array}$ & $\begin{array}{l}\text { 1) EarthCraft House }{ }^{\mathrm{T} M} \text { for } \\
\text { new homes } \\
\text { 2) EarthCraft House }{ }^{\mathrm{T} M} \\
\text { Renovation for existing homes }\end{array}$ & $\begin{array}{l}\text { 3-tiered point-based certification } \\
\text { (Certified, Gold, Platinum) } \\
\text { New construction - } 7 \text { categories } \\
{ }^{f} \\
\text { Renovation - } 5 \text { categories }{ }^{g}\end{array}$ & $\begin{array}{l}\text { Diagnostic tests, third party } \\
\text { verified } \\
\text { Gold and Platinum must meet } \\
\text { ENERGY STAR requirements }\end{array}$ & $\begin{array}{l}\text { Voluntary - homebuilders and } \\
\text { homeowners }\end{array}$ & $\begin{array}{l}\text { http://www.southface.org/green- } \\
\text { building-services/programs/earthcraft- } \\
\text { building-certification }\end{array}$ \\
\hline GreenPoint Rated & Build It Green (CA) & $\begin{array}{l}\text { Single and multifamily residential } \\
\text { new and existing } \\
\text { Offers two labels for existing single } \\
\text { family: Whole Home or Elements } \\
\text { Label }\end{array}$ & $\begin{array}{l}\text { Binary point-based certification - } \\
\qquad 5 \text { categories }{ }^{\mathrm{h}}\end{array}$ & $\begin{array}{l}\text { Third party verification from } \\
\text { GreenPoint Certified Rater }\end{array}$ & $\begin{array}{c}\text { Voluntary - offers bonus incentives } \\
\text { on top of utility rebates }\end{array}$ & $\begin{array}{c}\text { http://www.builditgreen.org/greenpoi } \\
\text { nt-rated/ }\end{array}$ \\
\hline Built Green ${ }^{T M}$ & $\begin{array}{l}\text { Master Builders Association } \\
\text { of King and Snohomish } \\
\text { Counties (WA) }\end{array}$ & $\begin{array}{l}\text { 1) Single family - new } \\
\text { 2) Residential remodel } \\
\text { 3) Multifamily } \\
\text { 4) Communities }\end{array}$ & $\begin{array}{l}\text { 5-tiered certification ( } 1 \text { to } 5 \text { stars) based } \\
\text { on point system for wide variety of } \\
\text { "green" attributes }\end{array}$ & $\begin{array}{l}\text { Self-certified via signed } \\
\text { checklist for } 1-3 \text { stars; third- } \\
\text { party verified for } 4 \text { or } 5 \text { stars }\end{array}$ & $\begin{array}{l}\text { Voluntary - developers, builders } \\
\text { and owners }\end{array}$ & http://www.builtgreen.net/ \\
\hline \multicolumn{7}{|l|}{ INTERNATIONAL } \\
\hline $\begin{array}{l}\text { Energy Performance } \\
\text { Certificate }\end{array}$ & $\begin{array}{l}\text { UK (Countries of the UK, to } \\
\text { comply with EU Energy } \\
\text { Performance of Buildings } \\
\text { Directive) }\end{array}$ & Residential - new and existing & Energy performance scale & SAP and RdSAP ${ }^{i}$ & $\begin{array}{l}\text { Required for all buildings } \\
\text { constructed, rented or sold }\end{array}$ & $\begin{array}{l}\text { http://www.direct.gov.uk/en/HomeAn } \\
\text { dCommunity/BuyingAndSellingYourHo } \\
\text { me/Energyperformancecertificates/ind } \\
\text { ex.htm }\end{array}$ \\
\hline R-2000 (EnerGuide) & $\begin{array}{l}\text { Natural Resources Canada } \\
\text { Office of Energy Efficiency } \\
\text { (Canada) }\end{array}$ & Residential - new & $\begin{array}{c}\text { Binary certification - energy/water use, } \\
\text { thermal quality, environmental } \\
\text { attributes }\end{array}$ & 3rd party evaluators & Voluntary - homebuilders & $\begin{array}{l}\text { http://oee.nrcan.gc.ca/residential/busi } \\
\text { ness/builders-renovators-trades/r- } \\
\text { 2000/about.cfm?attr=12 }\end{array}$ \\
\hline EnerGuide & $\begin{array}{c}\text { Natural Resources Canada } \\
\text { Office of Energy Efficiency } \\
\text { (Canada) }\end{array}$ & $\begin{array}{l}\text { Residential - new and existing } \\
\text { Commercial - benchmarking }\end{array}$ & Energy performance scale & 2nd party evaluators & $\begin{array}{l}\text { Voluntary - homebuilders and } \\
\text { homeowners }\end{array}$ & $\begin{array}{l}\text { http://oee.nrcan.gc.ca/energuide/inde } \\
\text { x.cfm }\end{array}$ \\
\hline
\end{tabular}

e Energy efficiency; indoor health; water conservation; materials; land use.

${ }^{\mathrm{f}}$ Site planning; energy efficiency; resource efficient design and construction; construction waste management; indoor air quality; water use; homebuyer education.

Energy efficiency, resource efficiency, water conservation, indoor air quality, durability.

${ }^{\mathrm{h}}$ Energy efficiency; water conservation; resource use in construction; indoor air quality; community benefit.

' Standard Assessment Procedure (SAP) for new homes; Reduced Data SAP (RdSAP) for existing homes. 


\section{Building Performance Labels Studies}

We summarize five recent studies from the U.S., Europe and Australia that were conducted to determine the extent to which energy efficiency or "green" labels may increase the market value of buildings (see Table 2 for details). Three of the studies are in the residential sector while two are from the commercial sector. Below is a summary of findings:

- Brounan and Kok (2010) found that 31,000 homes sold in the Netherlands between 2008 and 2009 that were "green” rated (A, B, or C rating) under the European Energy Performance Certificate garnered an average price premium of 3.7\%, compared to non-labeled homes. "A" rated homes sold for a $10.2 \%$ premium, while " $D$ ” labeled homes (below the "green” threshold) sold for an average of $5.1 \%$ less than non-labeled homes.

- The Earth Advantage Institute (2009) found that 92 new homes in Portland Oregon with Earth Advantage ${ }^{\circledR}$, Built Green ${ }^{\circledR}$ or ENERGY STAR certification sold for an average of $3 \%-5 \%$ more and sold an average of 18 days faster than comparable non-certified homes. In Seattle, Washington, 68 new homes with these certifications sold for an average of $9.6 \%$ more than comparable non-certified homes, but sold slightly more slowly.

- A study by the Australian Department of Water, Heritage, Environment and the Arts (2008) found that under the Australian Energy Efficiency Rating (EER) system (a 10-point rating scale of 1 to 5 stars at 0.5 star increments), 2,385 homes garnered an average price premium of $1.23 \%$ for each 0.5 EER star in 2005, and 2,719 homes sold for a 1.9\% premium for each 0.5 EER star in 2006.

- Eichholtz, Kok and Quigley (2009) conducted a study of large commercial office buildings in the U.S. that sold or rented between 2004 and 2007 (1,045 with ENERGY STAR certification, 286 LEED buildings and 29 buildings with both certifications). They found that ENERGY STAR certified buildings garnered an average sales price premium of $16 \%$ and an average rent premium of $3 \%$ per square foot, in aggregate, as compared to non-certified buildings located within 0.25 miles of each certified building. The authors found indications of possible price premiums for LEED buildings but could not report the findings as statistically significant due to the small sample size.

- Fuerst and McAllister (2009) conducted a similar study of certified commercial office buildings in the U.S., but used a larger data set (1,282 ENERGY STAR and 626 LEED certified buildings) and controlled for specific submarkets rather than using proximity to determine comparable properties. Their hedonic regression suggested rental premiums of 6\% and 5\% for LEED Gold and ENERGY STAR certification, respectively, and sales price premiums of 35\% and 31\% respectively.

\section{Methodologies}

Four of the five studies in this policy brief employed variations on a hedonic regression model, which can provide a high level of rigor and statistically sound results. A hedonic model isolates an extensive number of variable characteristics and calculates the price impact attributable to a particular characteristic (e.g., an energy efficiency or "green" label in this case). However, this approach requires the availability of a large 
dataset and access to enough data about the properties in question to adequately isolate the impact of energy performance and green attributes on property value. Two of the four studies were conducted in countries with mandatory labeling requirements (the Netherlands and Australia), thus large datasets of labeled homes were available. While a hedonic model can provide estimates of the average value that buyers place on particular attributes, it cannot fully account for the variation in value due to either heterogeneity in attributes (e.g., different types of bathroom remodels or different colors of interior paint that the model doesn't capture) or heterogeneity in homebuyers who value different attributes to different extents.

The Earth Advantage Institute study used a variation of a matched control group method. The researchers worked with residential real estate appraisers to develop a set of 3 to 4 nonlabeled properties with no distinguishing green features deemed satisfactorily closely comparable to each certified subject property in terms of seven objective or quantifiable attributes (i.e., sales date, location, style, quality, size, age, and sales price). For each set of subject and comparable properties, the average price difference was determined based on the judgment of experienced appraisers, taking into account both these objective attributes as well as subjective factors such as interior style or curb appeal. The percent difference in price was used to normalize the distribution of sales prices. While this approach relied on significantly fewer observations than the other studies, it benefitted from the input of experienced appraisers, who were able to take into account subjective attributes as well as objective attributes.

The Earth Advantage study also supplemented its research with interviews and surveys of residents and builders of certified homes to identify trends in public and industry perception

\section{The Hedonic Regression Method}

Hedonic regression is a method used to isolate the component parts of a good and determine the market value of each component through regression analysis using a large dataset and extensive number of variables. Hedonic models are commonly used in the housing market to estimate the value contributed by each of a house's characteristics (e.g., size, features and location) in order to estimate a sales price. A rigorous hedonic pricing model for home value should also account for other factors impacting sales price, (e.g., interest rates).

\section{The Matched Control Group Method}

The matched control group approach is a method for taking a member of a treated group of goods (e.g., labeled homes), and matching it with a group of comparable goods from a large pool of potential control subjects (e.g., non-labeled homes in the Earth Advantage study) based on characteristics that may have an impact on sales price (e.g., location and floor area). Researchers often use the matched control group method when there is a relatively small group of treated subjects and a much larger group of control subjects not exposed to the treatment. Because home characteristics vary widely, the Earth Advantage researchers developed a small comparison control group of 3 to 4 unlabeled homes for each labeled home, allowing them to use averaged price data for the matched control subject group. regarding residential green building and provide further context to the study results.

Two of the reports examined the market value for energy efficiency certification only, and two included an evaluation of a multi-attribute "green" certification. The commercial study is the only one of the four studies that applied a hedonic model to a "green” label (LEED). 
Table 2. Summary: Five Studies of the Value of Energy Performance and Green Attributes in Buildings

\begin{tabular}{|c|c|c|c|c|c|c|c|c|}
\hline Study & Label & Market & $\begin{array}{c}\text { Study } \\
\text { Objective }\end{array}$ & Data & $\begin{array}{c}\text { Application/ } \\
\text { Context }\end{array}$ & Methodology & Findings & URL \\
\hline $\begin{array}{l}\text { Brounan and Kok } \\
\text { (2010). On the } \\
\text { Economics of Energy } \\
\text { Labels in the } \\
\text { Housing Market. }\end{array}$ & $\begin{array}{l}\text { European Energy } \\
\text { Performance } \\
\text { Certificate (EPC), } \\
\text { based on thermal } \\
\text { quality. Scale: A++ } \\
\text { to G; A, B or C earns } \\
\text { "green" rating. } \\
\text { Certificate paid for } \\
\text { by seller. }\end{array}$ & $\begin{array}{l}\text { Nether- lands: } \\
\text { Existing } \\
\text { residential - } \\
\text { owner occupied } \\
\text { and rental. }\end{array}$ & $\begin{array}{l}\text { Study 1: } \\
\text { Understand } \\
\text { determinants for } \\
\text { label adoption. } \\
\text { Study 2: } \\
\text { Determine if } \\
\text { providing } \\
\text { information on EE } \\
\text { leads to sales price } \\
\text { premium for EE. }\end{array}$ & $\begin{array}{l}\text { 2008-2009: 31,993 } \\
\text { labeled homes, } \\
\text { 145,325 non- } \\
\text { labeled; sales price } \\
\text { between €10,000 } \\
\text { and €10M. }\end{array}$ & $\begin{array}{l}\text { EU requires certificate } \\
\text { disclosure in ads for } \\
\text { selling/renting and in } \\
\text { transfer documents. } \\
\text { Not fully mandatory - } \\
\text { homebuyers may sign } \\
\text { waiver relieving } \\
\text { seller's obligation to } \\
\text { certify home. Low } \\
\text { compliance. }\end{array}$ & $\begin{array}{l}\text { Study 1: Logit regression } \\
\text { model to understand } \\
\text { determinants of label } \\
\text { adoption. } \\
\text { Study 2: a) analyzed public } \\
\text { opinion of label, developed } \\
\text { probit model on likelihood } \\
\text { labeled home is non-random; } \\
\text { b) estimated inverse Mills } \\
\text { ratio and related the } \\
\text { dependent variable (price } \\
\text { per square foot), to set of } \\
\text { hedonic characteristics (e.g., } \\
\text { label, building attributes). }\end{array}$ & $\begin{array}{l}\text { +3.7\% avg price } \\
\text { premium for homes } \\
\text { labeled A, B, C., all other } \\
\text { things being equal. } \\
+10.2 \% \text { price premium } \\
\text { for "A" homes; } 5.1 \% \\
\text { discount for "D" labeled } \\
\text { homes. }\end{array}$ & $\begin{array}{l}\text { http://urbanpolicy.b } \\
\text { erkeley.edu/pdf/BK } \\
\text { _Energy_Labels_NK0 } \\
\text { 82410_wcover.pdf }\end{array}$ \\
\hline $\begin{array}{l}\text { Earth Advantage } \\
\text { (2009). Certified } \\
\text { Home Performance: } \\
\text { Assessing the } \\
\text { Market Impacts of } \\
\text { Third Party } \\
\text { Certification on } \\
\text { Residential } \\
\text { Properties. }\end{array}$ & $\begin{array}{l}\text { Earth Advantage }{ }^{\oplus} \text {, } \\
\text { Built Green }{ }^{\circledR} \text { or } \\
\text { ENERGY STAR } \\
\text { certified homes. }\end{array}$ & $\begin{array}{l}\text { New single } \\
\text { family homes - } \\
\text { U.S. Pacific } \\
\text { Northwest. }\end{array}$ & $\begin{array}{l}\text { Determine market } \\
\text { price premium for } \\
\text { third-party } \\
\text { sustainable } \\
\text { certified homes in } \\
\text { Seattle and } \\
\text { Portland metro } \\
\text { area. }\end{array}$ & $\begin{array}{c}\text { Portland: } 92 \\
\text { certified homes, } \\
340 \text { uncertified } \\
\text { comps. Seattle: } 68 \\
\text { certified, } 207 \\
\text { uncertified. 2000- } \\
\text { 2008; most homes } \\
\text { sold in 2006-2007. }\end{array}$ & $\begin{array}{c}\text { Voluntary - new } \\
\text { housing } \\
\text { developments }\end{array}$ & $\begin{array}{l}\text { Analyzed sample of certified } \\
\text { homes and comparable non } \\
\text { certified homes that met } 8 \\
\text { criteria* determined by } \\
\text { appraiser (3-4 comps per } \\
\text { certified home). For each } \\
\text { subject and its comps, } \\
\text { calculated avg price } \\
\text { difference and } \% \text { change to } \\
\text { normalize distribution of } \\
\text { home prices. }{ }^{c}\end{array}$ & $\begin{array}{l}\text { Portland: avg of }+3 \%-+5 \% \\
\text { sales price premium for } \\
\text { certified homes and sold } \\
\text { an avg of } 18 \text { days faster. } \\
\text { Seattle: avg of }+9.6 \% \\
\text { sales price premium but } \\
\text { sold slightly more } \\
\text { slowly. }\end{array}$ & $\begin{array}{l}\text { http://pacenow.org/ } \\
\text { documents/seattle_ } \\
\text { green_real_estate_p } \\
\text { remium.pdf }\end{array}$ \\
\hline
\end{tabular}

${ }^{a}$ From January 2008 to August 2009, 25\% of 177,000 sold homes had a label. In Sept 2009 adoption rate dropped to < $7 \%$ of homes for sale; coincides with negative press from real estate industry.

${ }^{b}$ The Northwest Multiple Listing Service provides information on sales of homes with Build Green, ENERGY STAR or LEED for Homes certification; The Regional Multiple Listing Service allows brokers to list homes as Earth Advantage or a co-branded combination of Earth Advantage, ENERGY STAR or LEED for Homes.

${ }^{\mathrm{c}}$ To account for different number of comperable homes per each subject home, a weighted average was calculated to determine differences in sales price. 


\section{Table 2. Summary: Five Studies of the Value of Energy Performance and Green Attributes in Buildings (continued)}

\begin{tabular}{|c|c|c|c|c|c|c|c|c|}
\hline Study & Label & Market & $\begin{array}{c}\text { Study } \\
\text { Objective }\end{array}$ & Data & $\begin{array}{c}\text { Application/ } \\
\text { Context }\end{array}$ & Methodology & Findings & URL \\
\hline $\begin{array}{l}\text { Australian } \\
\text { Department of } \\
\text { Water, Environment, } \\
\text { Heritage and the } \\
\text { Arts (2008). Energy } \\
\text { Efficiency Rating and } \\
\text { House Price in the } \\
\text { Act }\end{array}$ & $\begin{array}{l}\text { Energy Efficiency } \\
\text { Rating (EER); limited } \\
\text { to building shell } \\
\text { thermal } \\
\text { performance. } 10- \\
\text { point rating scale (1- } \\
5 \text { stars at } 0.5 \text { star } \\
\text { increments). }\end{array}$ & $\begin{array}{l}\text { Existing single } \\
\text { family homes, } \\
\text { Australian } \\
\text { Capital } \\
\text { Territory. }\end{array}$ & $\begin{array}{l}\text { Assess impact of } \\
\text { energy rating on } \\
\text { housing sale } \\
\text { prices. }\end{array}$ & $\begin{array}{l}2,385 \text { homes in } \\
2005 ; 2,719 \text { homes } \\
\text { in } 2006\end{array}$ & $\begin{array}{l}\text { Mandatory time-of- } \\
\text { sale disclosure of } \\
\text { energy efficiency } \\
\text { rating, disclosed early } \\
\text { in the home } \\
\text { marketing process. } \\
\text { High level of } \\
\text { compliance. }\end{array}$ & $\begin{array}{c}\text { Regression analysis of all } \\
\text { sales within a given year; } \\
\text { hedonic analysis estimates } \\
\text { value of each of } 13 \text { isolated } \\
\text { variables to arrive at value of } \\
\text { label. }{ }^{d}\end{array}$ & $\begin{array}{c}\text { 2005: }+1.23 \% \text { avg price } \\
\text { premium for each } 0.5 \\
\text { EER star. } 2006:+1.91 \% \\
\text { price premium per each } \\
0.5 \text { star } \\
\text { Roughly equivalent to } \\
\$ 9,000 \text { USD per whole } \\
\text { star. }\end{array}$ & $\begin{array}{l}\text { http://www.nathers } \\
\text {.gov.au/about/publi } \\
\text { cations/pubs/eer- } \\
\text { house-price-act.pdf }\end{array}$ \\
\hline $\begin{array}{l}\text { Eichholtz, Kok and } \\
\text { Quigley (2009). } \\
\text { Doing Well by Doing } \\
\text { Good? An Analysis of } \\
\text { the Financial } \\
\text { Performance of } \\
\text { Green Office } \\
\text { Buildings in the USA. }\end{array}$ & $\begin{array}{l}\text { Two labels: Energy } \\
\text { Star (thermal } \\
\text { efficiency) ; LEED } \\
\text { (range of green } \\
\text { building attributes). }\end{array}$ & $\begin{array}{c}\text { Large } \\
\text { commercial } \\
\text { office buildings; } \\
\text { U.S. } \\
\text { nationwide. } \\
\text { New } \\
\text { construction } \\
\text { and major } \\
\text { renovations. }\end{array}$ & $\begin{array}{l}\text { Assess impact of } 2 \\
\text { different building } \\
\text { rating systems on } \\
\text { building resale } \\
\text { value and rent } \\
\quad \text { values. }\end{array}$ & $\begin{array}{l}694 \text { buildings with } \\
\text { rental data; } 199 \\
\text { buildings sold } 2004- \\
2007 \text { - from Co-Star } \\
\text { dataset of large } \\
\text { commercial } \\
\text { buildings }\end{array}$ & Voluntary & $\begin{array}{l}\text { Developed list of non- } \\
\text { labeled comparables - } \\
\text { identified every building } \\
\text { within } .2 \text { mile of each labeled } \\
\text { building. Hedonic model } \\
\text { isolated many variables that } \\
\text { affect price (e.g., building } \\
\text { size, age, amenities, location, } \\
\text { area employment growth in } \\
\text { the services sector). }\end{array}$ & $\begin{array}{l}\text { ENERGY STAR: sales price } \\
\text { premium } 16 \% \text {, rent } \\
\text { premium } 3 \% \text { per sq. } \mathrm{ft} \text {. } \\
\text { LEED: indications of } \\
\text { potential sales } \\
\text { premiums found to be } \\
\text { not statistically } \\
\text { significant due to small } \\
\text { sample size. }\end{array}$ & $\begin{array}{l}\text { http://www.rics.org } \\
\text { /site/download_fee } \\
\text { d.aspx?fileID=5763\& } \\
\text { fileExtension=PDF }\end{array}$ \\
\hline $\begin{array}{c}\text { Fuerst and } \\
\text { McAllister (2009). } \\
\text { New Evidence on } \\
\text { the Green Building } \\
\text { Rent and Price } \\
\text { Premium. }\end{array}$ & $\begin{array}{l}\text { Two labels: Energy } \\
\text { Star (thermal } \\
\text { efficiency) ; LEED } \\
\text { (range of green } \\
\text { building attributes). }\end{array}$ & $\begin{array}{c}\text { Large } \\
\text { commercial } \\
\text { office buildings; } \\
\text { U.S. } \\
\text { nationwide. } \\
\text { New } \\
\text { construction } \\
\text { and major } \\
\text { renovations. }\end{array}$ & $\begin{array}{l}\text { Assess impact of } 2 \\
\text { different building } \\
\text { rating systems on } \\
\text { building resale } \\
\text { value and rent } \\
\quad \text { values. }\end{array}$ & $\begin{array}{l}626 \text { LEED and 1,282 } \\
\text { ENERGY STAR } \\
\text { certified buildings } \\
\text { from Co-Star } \\
\text { dataset }\end{array}$ & Voluntary & $\begin{array}{l}\text { 2-stage approach: 1) hedonic } \\
\text { regression model that } \\
\text { includes controls for location } \\
\text { effects using Co-Star defined } \\
\text { submarkets. 2) matched peer } \\
\text { group based on logistic } \\
\text { regression. Both results are } \\
\text { compared. }\end{array}$ & $\begin{array}{l}\text { Hedonic regression } \\
\text { findings: rental premium } \\
\text { of } 6 \% \text { for LEED, } 5 \% \text { for } \\
\text { ENERGY STAR. Sales } \\
\text { premium } 35 \% \text { for LEED, } \\
31 \% \text { for ENERGY STAR. }\end{array}$ & $\begin{array}{c}\text { http://www.reading } \\
\text {.ac.uk/rep/fulltxt/07 } \\
\text { 09.pdf }\end{array}$ \\
\hline
\end{tabular}

${ }^{d}$ The 13 variables were in 5 categories: 1) structural 2) community location 3) neighborhood attributes; 4) block location; 5) energy efficiency variables.

e Findings for ENERGY STAR certified buildings also include: 1 ) each $\$ 1$ in energy savings from increased thermal efficiency correlated to an additional \$18 in sales price; 2 ) the sales price premium was more pronounced in smaller markets and metro area peripheries than in central urban areas. 


\section{Recommendations}

These studies suggest that homebuyers and commercial building owners may pay more for a building that they know is rated as energy efficient. However, given the limited evidence, more studies are clearly needed to build a larger body of support for the market value of building labels, particularly in regard to the value of "green" labels that tout benefits in addition to the financial advantages of energy efficiency.

Hedonic pricing models and appraiser valuations have been used for many years by the real estate market to determine home prices and the value of properties' components. Given larger datasets and data points as the number of labeled or rated homes grows, and applying these methods, future studies may well be able to quantify the value of "green" and energy efficiency upgrades with increasingly reliable results.

Based on our literature review and investigation of existing efforts to evaluate the benefits of energy efficiency and green buildings, we make the following recommendations. These recommendations apply both to communities looking to promote energy efficiency and "green" certifications, and to researchers (who may be working with those communities) that want to add to this body of research.

- Timing of the release of the labeling or rating information is key to the sales price impact of the label. In order to maximize the value, the label or rating must be disclosed early in the sales process (in the list of building attributes/as part of the marketing process).

- The vintage of label matters. The energy efficiency attributes of ENERGY STAR Version 1 Qualified Homes should be expected to be significantly less valuable than for ENERGY STAR Version 3 qualified Homes, which meet much more stringent requirements. ${ }^{4}$ Researchers attempting to compare results across studies need to consider whether the homes being studied have comparable certification; comparing homes with different vintages or types of labels makes analysis very complicated.

- The type of label matters. Both of the large commercial studies found sales price premiums for an energy efficiency label (ENERGY STAR); however one of the studies was not able to find statistically significant price premiums for the "green” label (LEED), from its relatively small data set of buildings with that certification. While the price drivers in the residential market are different from those in the commercial market, communities and researchers may want to consider different approaches for evaluating energy efficiency vs. "green” labels. In particular, programs and communities working with "green" labels may be well-served to learn how much homebuyers in their region value various specific attributes (e.g., energy/resource efficiency vs. other benefits) when considering a labeled home, in order to inform marketing and messaging about the benefits of the label.

\footnotetext{
${ }^{4}$ ENERGY STAR Qualified Homes Version 1 (1995-2005) required homes to be 30\% more efficient than a home built to the 1992 Model Energy Code. ENERGY STAR Qualified Homes Version 2 (2006-2011) equated to 15\% more efficient than International Energy Conservation Code (IECC) 2004. ENERGY STAR Qualified Homes Version 3 (phasing in during 2011-2012) equates to 15-20\% more efficient than IECC 2009.
} 
- Collaborative efforts are needed in order to develop a robust dataset necessary to produce a rigorous study. Communities wishing to conduct a local or regional study as part of efforts to promote increased adoption and value of building labels would be advised to:

o Start with, or develop, a large enough dataset of labeled buildings and comparable nonlabeled buildings that have sold to produce statistically significant results;

o Gain access to enough data points from the sold and comparable homes to allow for development of an extensive list of variables in order to develop regression models; and

o Work with various entities to assure that the energy efficiency or "green" certification is prominently featured in the description and marketing of certified homes for sale.

- Work with local/regional MLS to modify their databases to include a new certification field.

- Work with realtors to include green label information, including associated attributes, in marketing for every listing that bears the label.

- Work with the county assessor's office to get green labeling and associated attributes attached to the property.

- Work with property appraisers to account for green attributes (e.g., energy and water use, indoor air quality) when assessing a certified home.

- Work with financing institutions to encourage the use of energy efficiency mortgages which can be tied to energy efficiency or "green" labels.

- Work with building inspectors as part of an effort to bring efficient and nonefficient attributes to the attention of prospective homebuyers.

- The precise approach used to assess market value for a label may depend on the type of certification and market penetration of the label. If a large enough number of labeled homes have sold and there is access to extensive data about the labeled and non-labeled comparisons, hedonic models can be used effectively. Where the available dataset and/or resources may not be large enough to provide statistically significant results using a hedonic model, a matched sampling method may be the most practical choice. Finally, supplementing research with homebuyer survey data may be helpful.

- If working with an appraiser to develop sets of comparable properties, the number of variables that are isolated and accounted for should be as large as feasible. Although it found indications that homebuyers value "green" labeled homes more than non-labeled homes, Earth Advantage might have been well-served to include more variables (e.g., interest rates, utility bills or resource usage, more variables for subtle differences in location and building design) in order to provide convincing support that the price premium was due to the label.

- Use surveys to provide additional context for complex market drivers. For communities wishing to increase the adoption of a "green" label and understand how best to maximize its market value, it may be helpful to survey buyers of certified homes as well as a random sample of all potential homebuyers to understand to what extent they value the various attributes that are represented by the label (e.g., quantifiable financial benefits of fuel and water savings vs. other attributes such as comfort, environmentally friendly materials, indoor air quality). 